\title{
NUTRITIONAL EVALUATION AND METHANE PRODUCTION OF SOME FODDER PLANTS USING IN VITRO GAS PRODUCTION TECHNIQUE
}

\author{
Afaf Abd El Rahman El Shereef ( El Shereef A. A. ) 1,2 \& Raafat Mahmoud Mohamed Gomaa (Gomaa R. M. \\ M. $)^{3,4}$ \\ 1. Laboratory of Climate Change and Livestock Production, Department of Animal Nutrition,Faculty of Veterinary Medicine and Animal \\ Science, University of Yucatan, Merida, Yucatan, Mexico \\ 2. Animal and Poultry Nutrition Department, Desert Research Center, El-Matareya, Cairo, Egypt \\ 3. Facultad de Medicina Veterinaria y Zootecnia, Universidad Autónoma del Estado de México, Toluca, México. \\ 4. Department of animal production, Faculty of Agriculture, Ain Shams University, Cairo, Egypt.
}

\section{Email: afafelshereef@gmail.com}

\begin{abstract}
The aim of this study was to evaluate the nutritive value of four salt tolerant plants (Pennisetum americanum, Acacia saligna, Leucaena leucocephala and kochia indica) based on their chemical composition, in vitro gas production and fermentation kinetics. The chemical composition of A. saligna and L. leucocephala showed the higher content of crude protein and non-protein nitrogen (NPN) as well. Total tannins, phenols and saponin contents in A. saligna and L. leucocephala was higher compared to $K$ indica. While $P$ americanum was free of total tannins and saponin. A significant differences were observed in short-chain fatty acids and acetic acid for the tested plants. Cumulative gas production for A. saligna, $L$. leucocephala and $K$ indica showed pronounced methane inhibition compared to $P$ americanum. The results indicated that the salt-tolerant plants used in the experiment could be promising feed resources to decrease energy loss as methane in ruminant diets. However, the presence of secondary metabolites and protein nitrogen (NPN) should be taken into consideration when formulating diets containing salt-tolerant forages for small ruminants.
\end{abstract}

Keywords: salt-tolerant plants, digestibility, rumen fermentation, methane production 


\section{INTRODUCTION}

In Egypt, the availability of forage feeds is more restricted particularly in areas with dry to semi-dry climate. Halophytes and other salt-tolerant plants have the advantage of tolerating high salt levels in the saline lands and drought conditions (Helal et al., 2013). These plants can provide great potentialities particularly as sources of livestock fodders and can fill up the feed gaps in the summer (Aderao et al. 2018). In the current study four fodder plants, Acacia saligna, Leucaena leucocephala, Kochia indica and Pennisetum americanum will present as salt-tolerant plants which could be used for feeding ruminants.

Acacia and Leucaena species are belonging to family Fabacea, and characterized as a drought resistant, moderately salinity tolerant, have high production of green biomass and high crude protein content (El Shaer 2010 \& Shaker et al., 2014). K indica are annual shrubs which belong to the family Chenopodiaceae, these plants are adapted to be grown under drought and /or salt-affected lands (El Shereef 2016). Besides, $P$ americanum is a salt and drought tolerant grass that could be used successfully and safely for feeding ruminants in semi-arid regions (Fahmy et al., 2010). Because of that, there is a need to use the available forages from such plants (shrubs, trees, and grasses) for feeding livestock with low feed costs under desert conditions. So, the purpose of this study is to assess the nutritional values of these plants by evaluate nutrient digestibility, ruminal fermentation profiles and methane production at in vitro level.

\section{Material and methods}

\section{Sample collection and preparation}

Plant samples ( $P$ americanum, A saligna, $L$ leucocephala and $K$ indica) were collected from six different sites randomly selected in South Sinai of Egypt, Sinai Peninsula (200 km South East of Cairo), Egypt. Laboratory work was conducted at the Laboratory of Climate Change and Livestock Production of FMVZ-UADY, Mexico. The experimental procedures were approved and complied with the ethical standards set by the faculty. For each species, the plants were cut into small pieces $(3-5 \mathrm{~cm})$. Samples were then dried at $50^{\circ} \mathrm{C}$ for $48 \mathrm{~h}$ using a forced air oven to prevent enzymatic degradation of the phenolic compounds present in the plant matter (Makkar et al. 1993b). Once dry, $400 \mathrm{~g}$ of plant matter was ground in a Lab-Willey Grinder (code MSW-342- IN; 10122740) and sieved through a $2-\mathrm{mm}$ screen. The grounded material was mixed well and then $100 \mathrm{~g}$ were sub-sampled, reground and passed through a $0.5-\mathrm{mm}$ screen sieve. These finely ground subsamples were used in tannin analysis while the rest of the material was used for in vitro gas production analysis. 


\section{The proximate analysis}

Dry matter (DM), crude protein (CP), crude fiber (CF) and ash of feed ingredients were determined according to AOAC (2007). Neutral detergent fiber (NDF) and acid detergent fiber (ADF) were determined using the ANKOM fiber technology technique (Robinson et al. 1999) without using alpha-amylase. The non-protein nitrogen (NPN) was obtained by precipitation of true protein in the filtrate with tungstic acid (10\% sodium tungstate solution) and determined as the difference between total $\mathrm{N}$ and the $\mathrm{N}$ content of the residue after filtration. Ammonia nitrogen were determined by Warner (1964). Determine of saponins was according to the method of Segal et al. (1966). Measurement of microbial protein was analyzed using the spectrophotometric method of Zinn \& Owens (1986) after incorporating suggested modifications of Makkar \& Becker (1991) and Obispo \& Dehority (1999). Microbial counts as bacteria and protozoa of ruminal fluid were determined using a counting cell (Hawskley, UK) as described by Demeyer (1981). Alkaloids concentration was determined according to Shamsa et al. (2007). Total oxalate was determined by HPLC method (Savage et al., 2000). $1 \mathrm{~mL}$ of $50 \%$ sulphuric acid was added and they were frozen at $-20{ }^{\circ} \mathrm{C}$ until analysis fractionation of SCFA's according to Erwin et al. (1961). Calcium was determined by spectrophotometer (Gindler and King, 1972). Inorganic phosphorus was determined by atomic absorption spectrophotometer according to Chapman and Pratt (1961). Sodium (Na) and potassium (K) were determined by using the standard flame photometry (Jackson, 1958) while copper (Cu), and zinc (Zn) concentrations were tested using atomic absorption techniques.

\section{In vitro gas production}

Gas production (GP) was determined following Theodorou et al. (1994) technique. Rumen fluid was collected from Pelibuey hair sheep in pre-warmed insulted bottle. Samples weighing $0.999 \mathrm{~g}$ of each plant then placed in $125 \mathrm{ml}$ serum glass bottles, and approximately $90 \mathrm{ml}$ of buffered rumen fluid was added to each bottle. Once closed, the bottles were gently shaken and placed in a water bath at $39{ }^{\circ} \mathrm{C}$. Gas production measurements, for the samples incubated $72 \mathrm{~h}$, were taken hourly up to 8 hours after incubation, then every four (from 12- to 28), eight (from 36-to 60) and $72 \mathrm{~h}$ post incubation. After 24 and $72 \mathrm{~h}$, the incubation residue, respectively, was analyzed for digestibility of dry matter (DMD), organic matter (OMD) and the digestibility of neutral detergent fiber (DNDF) content using the ANKOM fiber technology technique (Robinson et al. 1999).

Phenols content was determined using the Folin-Ciocalteu method and tannins were measured using polyvinylpolypyrrolidone (PVPP) as described by Makkar et al. (1993b).

\section{Methane measurement}

Using a gas-tight syringe, gas samples were collected from each bottle at $24 \mathrm{~h}$ postincubation as in Bhatta et al. (2015) and Kaya et al. (2016). After the volume of gas 2020 November Edition | www.jbino.com | Innovative Association 
was recorded, and the sample removed for methane analysis, the remaining gas was released. The $\mathrm{CH} 4$ content was determined by injecting $1 \mathrm{ml}$ of gas into a Perkin Elmer gas chromatograph (model: Clarus 500 series) equipped with a flame ionized detector (FID). Separation was achieved using an Elite-Q Plot Capillary Column (Perkin Elmer) packed with a 60/80 mesh carboxenTM-1000 stationary phase. Nitrogen was used as the carrier gas with a flow rate of $30 \mathrm{~mL}-1 \mathrm{~min}$, an isothermal oven temperature of $50 \circ \mathrm{C}$, and an injector temperature of $250 \circ \mathrm{C}$. The calibration curve using a regression equation was completed with standard $\mathrm{CH} 4$ (99.99\% from ALTECH).

\section{Statistical analysis}

The data obtained from each plant were analyzed for variance using an ANOVA procedure according to SAS (2000) using the following model: $Y i j=\mu+a i+\varepsilon i j$ where Yij is observation, $\mu$ is overall mean, ai is plant species ( $i=1$ to 4 ), and zij is error. Tukey's test was used for the multiple comparisons among mean values for the four plants and the significance level was set at $p<0.05$.

\section{Results and discussion}

\section{Proximate analysis}

The chemical composition is the first step to evaluate the nutritive value of such plants to be a feed for animals. Although $A$ saligna and L leucocephala were high in CP $(113$ and $147 \mathrm{~g} / \mathrm{kg})$, the nitrogen richness of such plants may not be fully used by ruminants since non-protein nitrogen (NPN) represents 46 and $52 \%$ of CP content, respectively (Table 1). The NPN could not be metabolized and converted to protein in the rumen if there is not sufficient energy source or some of these compounds would be converted to ammonia in the rumen, which is absorbed and converted to urea then excreted in the urine (SCA, 2007). Otherwise $K$ indica had moderate contents of CP and NPN \%. While $P$ americanum had the lowest $C P$, NPN and ADL contents compared with the other plants. In this regards, forages with $\mathrm{CP}$ content of less than $70 \mathrm{~g} / \mathrm{kg}$ DM require protein supplementation to offset limitations on voluntary feed intake as recommended by Melaku et al. (2003). The present study suggest that crude protein (CP) is inadequate estimation for salt tolerant plants of true protein because it is based on the assumption (certainly untrue) that all nitrogen in the biomass will become protein; i.e. CP $(\%)=$ nitrogen $(\%)$ * 6.25 .

The differences in cell wall constituents as NDF, ADF and ADL could be due to species genotypic differences for the tested plants and their values were agreed with Shawket et al. (2010), Shaker et al. (2014) and El Shereef (2016).

\section{Plant secondary metabolites (PSM) and minerals}

PSM is a group of chemical bioactive compounds such as tannins, saponins, alkaloids, flavonoids, glucosides, etc., that are not involved in the primary biochemical processes of growth and reproduction, but play a vital role in the interaction between plants and the 
environment (Kliebenstein 2013). A saligna and $L$ leucocephala showed higher alkaloids, saponin, and phenols components compared to the other plants (Table 2). Both plants had alkaloids content above $40 \mathrm{~g} / \mathrm{kg}$ DM. Ventura et al. (2000) recorded the negative correlation between feed intake and alkaloids content. Besides, Abd El-Rahman (2003) reported that Halocnemum strobilaceum and Hammada elegans which consider non palatable plants was related to high level of alkaloids (31.1 and $61.6 \mathrm{~g} / \mathrm{kg} \mathrm{DM}$ ). Likewise, saponins are characterized by a bitter taste and foaming properties (Kumar, $2011)$. Thus the present results of alkaloids and saponins concentrations could explain the lower dry matter intake from A saligna and $L$ leucocephala in different studies (Shawket et al., 2010, Helal et al. 2013 and Hassan et al. 2015) compared to traditional rations. Concerning condensed tannins (CT), it was reported that moderate levels (30 to $40 \mathrm{~g} / \mathrm{kg} \mathrm{DM}$ ) of CT may result in nutritional advantages by increased bypass protein availability and bloat suppression in cattle. The mode of action of condensed tannins lat low concentrations) was noticed by bind with plant protein at nearly neutral $\mathrm{pH}$ in the mouth and rumen to form tannin-protein complexes which are stable and insoluble at $\mathrm{pH} 3.6-7.0$, but dissociate and release protein at $\mathrm{pH}<3.5$ in the abomasums (Soltan et al., 2013). Therefore, the presence of high contents of CT should be taken into consideration when formulating diets containing the tested plants for feeding ruminants.
Total oxalate was higher in $K$ indica compared to the other plant species. El Shereef et al. (2016) reported a significant inhibition for $\mathrm{Ca}$ concentration in blasma for sheep fed $K$ indica silage, the authors suggests that $\mathrm{Ca}$ bioavailability may decrease as result of the binding with $\mathrm{Ca}$ to form calcium oxalate, a non-soluble and non-digestible compound. $P$ americanum was free of total tannins, condensed tannins and saponin. In general, the concentrations of alkaloids, saponin, total tannins, total oxalate and condensed tannins contents for the experimental plants were comparable to that obtained by El Shereef et al. (2016) and Fahmy \& Ibrahim (2005) for K indica and $P$ americanum while these values was above than that reported by Bueno et al. (2005) and Soltan et al. (2012) for A saligna and $L$ leucocephala. This variation could be due to many factors like temperature, drought, salinity, seasonality, altitude and light, metal ions, wounding and nutrient deficiencies can affect their concentration and these are also dependent on the growing conditions and metabolic pathways of related PSM (Gouvea et al. 2012).

In respect to minerals values (Table 2), it seems that $A$ saligna and $L$ leucocephala could be good resource of Ca for feeding animals. $K$ indica and $A$ saligna surpassed the other plants in $\mathrm{Na}$ contents while $P$ americanum had the highest $P$ concentration. This finding was agreed with Helal et al., (2013). A wide variation of the other minerals concentrations are recorded for the experimental plants, these was in harmony with the finding by 
El Shaer (2016) when he set that salt tolerant plants are characterized by moderate digestible crude protein, soluble carbohydrates and high mineral contents, particularly $\mathrm{Na}, \mathrm{K}, \mathrm{Cl}$ and $\mathrm{Ca}$ concentrations.

\section{In vitro fermentation profiles}

As expected, in vitro fermentation parameters differed $(P<0.05)$ among plant species (Table 3). A saligna and $L$ leucocephala releasing a lower ruminal $\mathrm{NH} 3-\mathrm{N}$ concentration resulting a significant decreasing in $\mathrm{pH}$ values compared to $K$ indica plant. This may be associated with the protection of dietary protein from microbial activity by binding tannin-protein complexes which are stable and insoluble at $\mathrm{pH}$ 3.6-7.0 as mention in Table 2. While $P$ americanum releasing the lowest ruminal $\mathrm{NH} 3-\mathrm{N}$ and lower $\mathrm{pH}$ which may be attributed to their lower nitrogen components (CP and NPN) as shown in Table 1.

Total short chain fatty acid (SCFA's) and acetic acid was higher $(P<0.05)$ for $K$ indica and $P$ americanum compared to the other plants. Otherwise the results showed that, A saligna, L leucocephala and $K$ indica presented a pronounced $\mathrm{CH} 4$ inhibition while $P$ americanum significantly decreased ruminal bacteria. The major challenge of utilize salt-tolerant plants is that their high cell wall contents, phenolic compounds, with variable mineral concentration. As indicated in the present study for the experimental plants species which have a considerable proportion of condensed tannins that may form complexes with proteins and carbohydrates resulting in reduction of their ruminal fermentation. Even though, this generally increases efficiency of ruminal $\mathrm{N}$ utilization and intestinal input of $\mathrm{N}$, it can restrict fiber digestion in the rumen, resulting in unsynchronized availability of $\mathrm{N}$ and energy to microbes for synthesis VFA (Attia et al. 2018). So, it could be explain the lower SCFA's and acetic acid for rich phenolic plants (Table 2). The variable responses of in vitro gas production among plants could be due to variable levels of PSM. It is noticeable the higher tannins and saponins contents for $A$ saligna and L leucocephala plants (Table 2) that reflect in reduction of total gas, methane production and total number of ruminal Bacteria as well (Table 3). In this regards, the anti-methanogenic activity of tannins has recently been reported by many studies (Goal and Makkar, 2012 and Liu and Zhou, 2011) the mechanism of tannins may be due to inhibit ruminal microorganisms through bactericidal or bacteriostatic activities, the growth or activity of rumen methanogens and protozoa. However, Saponins have a potent antimicrobial activity and limit the $\mathrm{H} 2$ availability for methanogenesis in the rumen, thereby could reduce $\mathrm{CH} 4$ production (Bodas et al. 2012 and Patra \& Saxena, 2009).

\section{In vitro nutrients digestibility}

The variations of in vitro digestibility values (Table 4) could be due to variable levels of phenolic, tannin activity and cell wall content among the experimental plants. The high IVDMD, IVOMD and IVNDFD for $P$ americanum could be due to the lower com | Innovative Association 
phenolic components, absence of condensed tannin and saponin. The lower digestibility of $A$. saligna, L leucocephala could be attributed to the higher concentration of condensed tannins through formation of complexes with dietary carbohydrates which is associated with reduction in organic matter digestibility. Moreover, other researchers (Min et al. 2003 and Ammar et al. 2005) reported that concentrations of condensed tannins are negatively correlated with in vitro dry matter degradability. The result of all nutrients digestibility of the experimental plants was lower than that recorded by Hassan et al. (2015) and Shawket et al. (2010) at in vivo level, this mainly attributed to supplemented the salt-tolerant plants with different energy resources that could improve ruminal microbes for better utilization of their nutrients. 
Table 1. Chemical composition and fiber fraction of the experimental plants

\begin{tabular}{|c|c|c|c|c|}
\hline \multirow[t]{2}{*}{ parameters } & \multicolumn{4}{|c|}{ Plants } \\
\hline & $P$ americanum & A saligna & L leucocephala & $K$ indica \\
\hline $\mathrm{DM}(\mathrm{g} / \mathrm{kg})$ & 427 & 435 & 383 & 337 \\
\hline $\mathrm{CP}(\mathrm{g} / \mathrm{kg} \mathrm{DM})$ & 54 & 113 & 147 & 87 \\
\hline $\mathrm{NPN} *(\mathrm{CP} \%)$ & 13 & 46 & 52 & 43 \\
\hline $\mathrm{CF}(\mathrm{g} / \mathrm{kg} \mathrm{DM})$ & 287 & & & 276 \\
\hline $\mathrm{NDF}(\mathrm{g} / \mathrm{kg} \mathrm{DM})$ & 560 & & & \\
\hline $\mathrm{ADF}(\mathrm{g} / \mathrm{kg} \mathrm{DM})$ & 361 & 350 & 260 & 392 \\
\hline $\mathrm{ADL}(\mathrm{g} / \mathrm{kg} \mathrm{DM})$ & 64 & & 147 & \\
\hline Ash (g/kg DM) & 115 & 95 & 75 & 141 \\
\hline
\end{tabular}

$\mathrm{DM}=$ dry matter, $\mathrm{CP}=$ crud protein, $\mathrm{CF}=$ crud fiber, $\mathrm{NDF}=$ nutrient detergent fiber, $\mathrm{ADF}=$ acid detergent fiber, $\mathrm{ADL}=$ acid detergent lignin, ${ }^{*}$ The percentage of crude protein of the plant that is non-protein nitrogen $\mathrm{x} 6.25$. 
Table 2. Secondary metabolites and some minerals contents of the experimental plants

\begin{tabular}{|c|c|c|c|c|c|}
\hline \multirow{2}{*}{\multicolumn{2}{|c|}{ parameters }} & \multicolumn{4}{|c|}{ Plants } \\
\hline & & $P$ americanum & A saligna & L leucocephala & $K$ indica \\
\hline & Alkaloids (g/kg DM) & 11.9 & 77.9 & 42.4 & 21.0 \\
\hline & Total oxalate (g/kg DM) & 12 & 18.0 & 26.0 & 34.0 \\
\hline & Saponin (g/kg DM) & 0 & 105.6 & 64.8 & 38.1 \\
\hline & Total phenols (g/kg DM) & 5.6 & 95.1 & 103.0 & 34.7 \\
\hline & Total tannins (g/kg DM) & 0 & 75.0 & 89.0 & 48.3 \\
\hline & Condensed Tannins (g/kg DM) & 0 & 68.0 & 59.0 & 32.0 \\
\hline \multicolumn{6}{|l|}{$\underline{\text { Mineral contents }}$} \\
\hline & $\mathrm{Cu}(\mathrm{mg} / \mathrm{kg})$ & 35.8 & 17.0 & 7.8 & 6.5 \\
\hline & $\mathrm{Zn}(\mathrm{mg} / \mathrm{kg})$ & 60.1 & 41.8 & 30.8 & 29.4 \\
\hline & $\mathrm{K}(\mathrm{g} / \mathrm{kg} \mathrm{DM})$ & 15.0 & 21.5 & 17.5 & 6.5 \\
\hline & $\mathrm{Na}(\mathrm{g} / \mathrm{kg} \mathrm{DM})$ & 10.5 & 15.0 & 2.0 & 15.5 \\
\hline & $\mathrm{Ca}(\mathrm{g} / \mathrm{kg} \mathrm{DM})$ & 7.8 & 13.4 & 11.9 & 5.5 \\
\hline & $\mathrm{P}(\mathrm{g} / \mathrm{kg} \mathrm{DM})$ & 3.3 & 1.2 & 2.0 & 1.4 \\
\hline
\end{tabular}

$\mathrm{Cu}=$ copper, $\mathrm{Zn}=$ zinc, $\mathrm{K}=$ potassium, $\mathrm{Na}=$ sodium, $\mathrm{Ca}=$ calcium, $\mathrm{P}=$ phosphorus. 
Table 3. Comparative in vitro evaluation of the experimental plants on ruminal fermentation

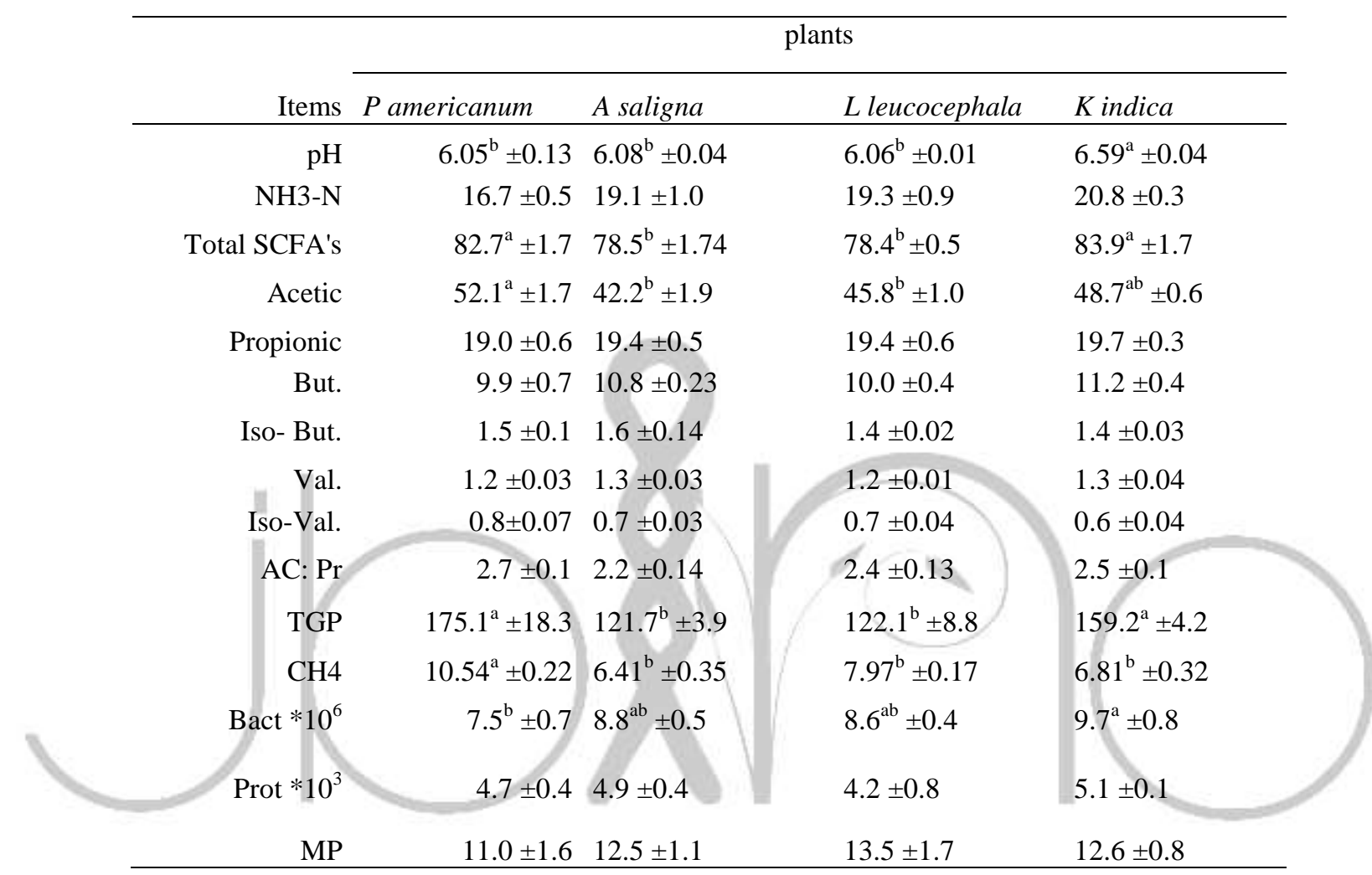

a,b,c Means having different superscripts within the same row differed significantly(P<0.05), otherwise no significant differences were detected. Total SCFA's = total short chain fatty acid, But. = Butyric acid, Val. = Valeric acid, AC = acetic acid, TGP = total gas production, CH4 = methane, Bact. $=$ Bacteria, Prot. $=$ protozoa, $\mathrm{MP}=$ microbial Protein. 
Table 4. in vitro nutrients digestibility of the experimental plants plants

L leucocephala

\begin{tabular}{ccccc} 
Items & $P$ americanum & A saligna & & K indica \\
\hline IVDMD & $488.3^{\mathrm{a}} \pm 7.4$ & $408.6^{\mathrm{c}} \pm 6.6$ & $366.7^{\mathrm{d}} \pm 5.9$ & $-453.5^{\mathrm{b}} \pm 5.6$ \\
IVOMD & $493.7^{\mathrm{a}} \pm 6.9$ & $397.3^{\mathrm{c}} \pm 6.2$ & $355.5^{\mathrm{d}} \pm 5.6$ & $459.1^{\mathrm{b}} \pm 6.9$ \\
IVNDFD & $443.7^{\mathrm{a}} \pm 13.8$ & $363.3^{\mathrm{b}} \pm 10.5$ & $329.6^{\mathrm{c}} \pm 11.0$ & $426.5^{\mathrm{a}} \pm 5.9$ \\
\hline IVCPD & $109.8 \pm 12.6$ & $116.6 \pm 6.0$ & $117.6 \pm 9.5$ & $127.9 \pm 10.5$ \\
b $135.4 \pm 4.4$ & $118.5 \pm 4.0$ & $116.8 \pm 2.3$ & $164.5 \pm 8.1$ \\
C & $0.09 \pm 0.01$ & $0.11 \pm 0.02$ & $0.11 \pm 0.01$ & $0.09 \pm 0.01$
\end{tabular}

IVDMD = in vitro dry matter digestibility, IVOMD = in vitro organic matter digestibility, IVNDFD = in vitro nutrient detergent fiber digestibility, IVCPD = in vitro crud protein digestibility, $\mathrm{b}, \mathrm{c}=$ fermentation kinetics. 


\section{Conclusion}

In conclusion, the results indicated that the salt-tolerant plants used in the experiment could be promising feed resources to decrease energy loss as methane in ruminant diets. However, the presence of secondary metabolites and protein nitrogen (NPN) should be taken into consideration when formulating diets containing salt-tolerant forages for feeding small ruminants.

\section{Acknowledgements}

The senior author thanks the Third World Academy of Science (TWAS; Trieste, Italy) and CONACYT-Mexico for granting a postdoctoral scholarship at FMVZ-UADY, Merida, Mexico.

\section{References}

Aderao G N, Sahoo A, Bhatt R S, Kumawat P K and Soni L. 2018. In vitro rumen fermentation kinetics, metabolite production, methane and substrate degradability of polyphenol rich plant leaves and their component complete feed blocks. J. Anim. Sci. Technol. 60:1-9

Ammar H, López S and González J S. 2005. Assessment of the digestibility of some Mediterranean shrubs by in vitro techniques. Anim. Feed Sci. Technol. 119:323-331.

AOAC - Association of Official Analytical Chemists. 2007. Official Methods of Analysis, 19th Edition, Washington, USA.
Attia M F A, Nasser M E A, Zeitoun M M, ElGendy M N, El-Shazly K A and Sallam S M A. 2018. Digestion of tanniniferous plants in ruminants. In vitro ruminal and post-ruminal protein digestion of some Egyptian tanniniferous plants. J. Food Agri. \& Envir. 16 (2): 100-107.

\section{Bhatta R, Saravanan M, Baruah L, Prasad C} S. 2015. Effects of graded levels of tannincontaining tropical tree leaves on in vitro rumen fermentation, total protozoa and methane production. J. Applied Microbiol. 118: 557-564.

Bodas R, Prieto N, García-González R, Andrés S, Giráldez F J, López S. 2012. Manipulation of rumen fermentation and methane production with plant secondary metabolites. Anim. Feed Sci. Technol. 176:78-93.

Bueno I C S, Filho $S$ L S, Gobbo $S$ P, Louvandini H, Vitti D M S S, and Abdalla A L. 2005. Influence of inoculum source in a gas production method. J. Anim Feed sci. Technol. 123, 95-105.

Chapman H I and Pratt P F. 1961. Methods analysis for soils, plants and waters. Uni. California. Kerkelcy. 309.

Demeyer D I. 1981. Rumen microbes and digestion of plant cell walls. Agric. Environ. 6: 295-337.

El-Shaer H M. 2010. Halophytes and salttolerant plants as potential forage for ruminants in the Near East region. Small Rumin. Res. 91: pp. 3-12. 
El Shaer H M. 2016. Impact of Halophytes and Salt Tolerant Forage Processing as Animal Feeds at Farm Level. Basic Guide lines. pp. 388-405. In: Hassan M. El Shaer and Victor R. Squires (Eds.). Halophytic and Salt-Tolerant Feedstuffs: Impacts on Nutrition, Physiology and Reproduction of Livestock .CRC Press, Taylor\& Francis Group.

El-Shereef A A. 2016. Kochia plant as potential forage for ruminants under desert conditions. Annual Res. and Rev. Biol. 10(2):1-6.

El Shereef A A, Helal H G, Eid E Y, Abo Bakr S, El Shaer H M and Fahmy A A. 2016. Improving Kochia indica plants utilization for feeding small ruminants under saline conditions of Sinai, Egypt. Internat. J Advanced Res. 4 (7) 2217-2224.

Erwin ES, Marco G T and Emery E M. 1961. Volatile fatty acid analysis of blood and rumen fluid by gas chromatography. J. Dairy Sci. 44: 1768-1771.

Fahmy A A and Ibrahim K M A. 2005. Feed utilization and performance of lambs fed Kochia indica shrubs under desert conditions of Sinai. Egypt. J. Desert Res. 55: 153-163.

Fahmy A A, Youssef K $M$, El Shaer $H$ M. 2010. Intake and nutritive value of some salt-tolerant fodder grasses for sheep under saline conditions of South Sinai, Egypt. Small Rumin. Res. 91:110-115.
Gindler M and King J D. 1972. Rapid colorimetric determinatation of calcium in biologicfluids with methylthymol blue. Am. J. Clinc. Path., 58:376-382.

Goel G and Makkar H P. 2012. Methane mitigation from ruminants using tannins and saponins. Trop. Anim. Health Prod. 44:729-39.

Gouvea D R, Gobbo-Neto L, Sakamoto H T. 2012. Seasonal variation in the major secondary metabolites present in extract of Eremanthus mattogrossensis Less (Asteraceae: Vernonieae) leaves. Quim Nova. 35(1 1):2139-2145.

Hassan A A, Abu Hafsa Salma $H$, Yacout $M$ $H$, Khalel M S, Ibrahim M A R, Dorina M. 2015. Effect of feeding some forage shrubs on goats performance and rumen fermentation in dry season. Egypt. J. Sheep \& Goat Sci. p 21-36.

Helal H G, Eid E Y, Nassar M S and El Shaer H M. 2013. Some nutritional studies of four salt-tolerant fodder crops fed to goats under saline conditions in Egypt. Egypt. J. Nutrit. \& Feeds. 16 (1): 65-78.

Jackson M L. 1958. Soil Chemical Analysis. Prentice-Hall Inc. Englewood Cliffs, NJ, 498 p.

Kaya E, Canbolat O, Atalay Al, Kurt O, Kamalak A. 2016. Potential nutritive value and methane production of pods, seed and senescent leaves of Gleditsia triacanthos trees. Livestock Res. for Rural Devel. 28(7): 123. 
Kliebenstein D J. 2013. Making new molecules: evolution of structures for novel metabolites in plants. Curr Opin Plant Biol 16: 112-117.

Liu H, Vaddella V, Zhou D. 2011. Effects of chestnut tannins and coconut oil on growth performance, methane emission, ruminal fermentation, and microbial populations in sheep. J Dairy Sci. 94(60):6977.

Makkar H P S, and Becker K. 1991. Purine quantification in digesta from ruminants by spectrophotometric and HPLC methods. Br. J. Nutr, 81:107-112.

Makkar H P S, Bluemmel M, Borowy, NK, Becker K. 1993. Gravimetric determination of tannins and their correlations with chemical and protein precipitation methods. J. the Sci. Food and Agric. 61: 161-165.

Melaku S, Peters K J, Tegegne A. 2003. In vitro and in situ evaluation of selected multipurpose trees, wheat bran and Lablab purpureus as potential feed supplements to tef (Eragrostis tef) straw. Anim. Feed Sci. Technol. 108:159-179.

\section{Min B R, Barry T N, Attwood G T and Mc} Nabb W. C. 2003. The effect of condensed tannins on the nutrition and health of ruminants fed fresh temperate forages: a review. Anim. Feed Sci. Technol. 106:3-19.

Moss A R, Jouany J P, Newbold J. Methane production by ruminants: its contribution to global warming. Ann Zootech. 2000:49:231-
Obispo N E \& Dehority B A. 1999. Feasibility of using total purines as a marker for ruminal bacteria. J. Anim. Sci., 77:30843095.

Patra A K, Saxena J. 2009. The effect and mode of action of saponins on the microbial populations and fermentation in the rumen and ruminant production. Nutr Res Rev. 22(20):4-19.

Robinson P H, Mathews M C, Fadel J G. 1999. Influence of storage time and temperature on in vitro digestion of neutral detergent fiber at $48 \mathrm{~h}$, and comparison to $48 \mathrm{~h}$ in sacco neutral detergent fiber digestion. Anim. Feed Sci. \& Technol. 80: 257-266.

SAS Institute. SAS user's guide: statistics (Vol. 2). 1985. SAS Institute, Cary, NC.

Savage G P, Vanhanen L, Mason S M, Ross A B. 2000. Effect of cooking on the soluble and insoluble oxalic acid content of some New Zealand foods. J Food Composit. \& Analysis. 13:201-206.

SCA. 2007. Standing Committee on Agriculture's Nutrient Requirements of Domesticated Ruminants. CSIRO 10 Publications, Melbourne, Australia.

Segal R, Mansour M, Zaitschek D V. 1966. Effect of ester groups on the haemolytic action of some saponins and sapogenins. Biochemic.Pharmacol. 15, 141 $1-1416$.

53. 
Shaker Y M, Ibrahim N H, Younis F E and El Shaer H M. 2014. Effect of Feeding Some Salt Tolerant Fodder Shrubs Mixture on Physiological Performance of Shami Goats in Southern Sinai, Egypt. J. Amer. Sci. 2014:10 (2S).

Shamsa F, Monsef H Re, Ghamooshi R and Verdian R M R. 2007. Spectrophotometric Determination of Total Alkaloids in Peganum harmala L. Using Bromocresol Green. Res. J. Phytochem. 1: 79-82.

Shawket S M, Ahmed M H and Ibrahim M A. 2010. Impact of feeding Atriplex Halimus and Acacia saligna with different sources of energy on lambs performance. Egyptian. J. Sheep \& Goat Sci. 5 (1): 191208.

Soltan Y A, Morsy A S, Sallam S M A, Louvandini H, Abdalla A L. 2012. Comparative in vitro evaluation of forage legumes (prosopis, acacia, atriplex, and leucaena) on ruminal fermentation and methanogenesis. J Anim Feed Sci 21, 759772.

Soltan Y A, Morsy A S, Sallam S M A, Lucas R C, Louvandini $H$, Kreuzer M, Abdalla A L. 2013. Contribution of condensed tannins and mimosine to the methane mitigation caused by feeding Leucaena leucocephala. Arch Anim. Nutrit. 67: 169184.

Theodorou M K, Williams B A, Dhanoa M S, McAllan A B, France J. 1994. A simple gas production method using a pressure transducer to determine the fermentation kinetics of ruminant feeds. Anim. Feed Sci. \& Technol. 48: 185-197.

Warner A C I. 1964: Production of volatile fatty acids in the rumen: Method of measurement. Nutr Abst and Rev., 34:339.

Zinn $\mathbf{R} \quad \mathbf{A}$ and Owens $\mathbf{F}$ N. 1986. A rapid procedure for purine measurement and its use for estimating net ruminal protein synthesis. Can. J. Anim. Sci., 66:157-166.

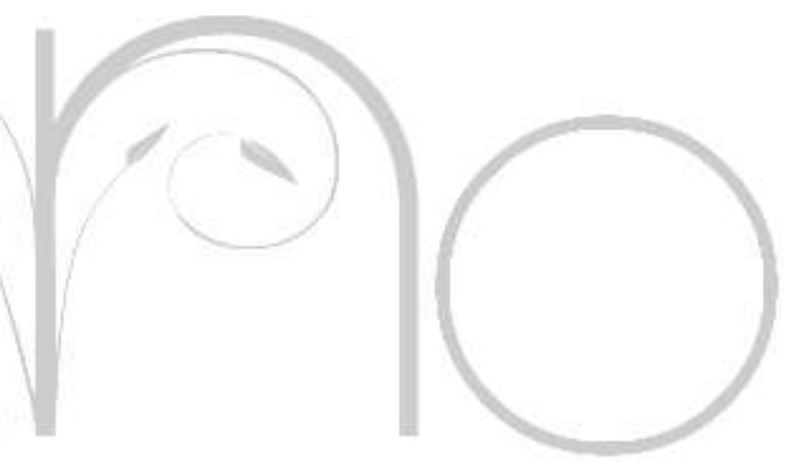

2020 November Edition | www.jbino.com | Innovative Association 